\title{
ANALISIS STRUKTURAL DAN ASPEK SOSIAL TERHADAP NOVEL SEBELAS PATRIOT KARYA ANDREA HIRATA
}

\author{
Visi Wintan Reka Widya Tampubolon \\ Jurusan Pendidikan Bahasa dan Sastra Indonesia \\ PPs Universitas Negeri Medan \\ visiwirewita@gmail.com
}

\begin{abstract}
Abstrak. Tujuan penelitian ini adalah untuk mendeskripsikan hasil analisis sktruktural dan aspek sosial terhadap novel Sebelas Patriot karya Andrea Hirata. Penilaian dari analisis struktural meliputi judul, tema, konflik, dan latar dan pada aspek sosial menunjukan suatu hubungan-hubungan sosial yang dinamis. Sehingga kajian ini dapat mempelajari interaksi sosial yang terjadi di dalam novel sesuai dengan realita sosial yang terdapat dalam masyarakat. Penelitian pada novel Sebelas Patriot karya Andrea Hirata menggunakan metode kualitatif. Dalam tahap analisis data, penulis akan mendeskripsikan analisis struktural dan aspek sosial. Langkah pertama yang dilakukan yaitu menganalisis novel Sebelas Patriot dengan menggunakan analisis struktural, kemudian langkah kedua yaitu menganalisis novel Sebelas Patriot dengan tinjauan aspek sosial.
\end{abstract}

Kata Kunci: Analisis Struktural, Aspek Sosial, Sebelas Patriot

\section{PENDAHULUAN}

Karya sastra merupakan tanggapan pengarang terhadap dunia dan realita sosial yang dihadapinya. Di dalam karya sastra berisi pengalaman-pengalaman subjektif penciptanya, pengalaman kelompok masyarakat atau fakta sosial. Sastra dapat dipandang sebagai suatu gejala sosial, sastra yang ditulis oleh pengarang pada suatu kurun waktu tertentu, pada umumnya langsung berkaitan dengan norma-norma dan adat-istiadat jaman itu. Oleh karena itu, dapat dikatakan bahwa terciptanya sebuah karya sastra tidak dapat lepas dari bagaimana situasi dan kondisi masyarakat pada saat sebuah karya sastra diciptakan. Proses penciptaan karya sastra selain dipengaruhi oleh situasi dan kondisi masyarakat juga dipengaruhi oleh situasi dan kondisi dalam diri penulis.

Novel merupakan salah satu jenis prosa yang mengisahkan suatu peristiwa dan perjalanan hidup yang disertai konflikkonflik sehingga membuat unsur penceritaan lebih berkembang dan hidup. Novel Sebelas Patriot merupakan kisah nyata dari seorang penulis novel yaitu Andrea Hirata. Andrea Hirata sering menceritakan pengalaman unik yang dikemas dalam sebuah novel seperti novel Laskar Pelangi, Sang Pemimpi, dan Edensor. Trilogi tersebut merupakan perekaan kembali cerita hidupnya yang dikemas dalam novel dan telah dibumbui oleh unsur-unsur sastra. Begitu juga pada novel yang berjudul Sebelas Patriot yang 
isinya mengenai kebanggannya terhadap ayah dan PSSI yang isinya sarat akan motivasi dan pendidikan. Novel Sebelas Patriot dikaji dalam aspek struktural dan aspek sosiologis.

Siswanto (2005:19) mengemukakan aspek struktural dapat pula disebut dengan pendekatan intrinsik, yaitu pendekatan yang berorientasi kepada karya sebagai jagad yang mandiri terlepas dari dunia eksternal di luar teks dimana analisis ditujukan kepada teks itu sendiri sebagai kesatuan yang tersusun dari bagian-bagian yang terjalin dan analisis dilakukan berdasarkan pada parameter intrinsik sesuai dengan keberadaan unsur-unsur internal.

Nurgiyantoro

(2000:36)

mengemkakan analisis strukturalisme dapat dipandang sebagai salah satu pendekatan kesastraan yang menekankan pada hubungan antara unsur-unsur pembangun karya sastra yang bersangkutan.

\section{Endraswara}

(2013:

mengemukakan strukturalisme berarti paham mengenai unsur-unsur, yaitu struktur organisasi dengan mekanisme antarhubungannya, di satu pihak antarhubungan unsur yang satu dengan unsur yang lainnya, di pihak lain hubungan antara unsur dengan totalitasnya sehingga merupakan salah satu cara untuk mengetahui kualitas sastra. Dari berbagai pendapat di atas dapat diambil kesimpulan bahwa analisis struktural merupakan suatu penelitian terhadap unsur-unsur intrinsik yang membangun karya sastra dalam kaitan dan hubungannya dalam membangun karya sastra tersebut.

Sosiologi sastra merupakan pendekatan yang bertitik tolak dengan orientasi kepada pengarang.

Soekanto (2003:52) mengatakan sosiologi sastra merupakan bagian mutlak dari kritik sastra, ia mengkhususkan diri dalam menelaah sastra dengan memperhatikan segi-segi sosial kemasyarakatan.

Teeuw (1983 : 25) mengatakan sosiologi sastra adalah penelitian terhadap karya sastra dan keterlibatan struktur sosialnya.

Wellek dan Austin Warren (1977 :87) mengatakan bahwa sosiologi sastra yakni mempermasalahkan suatu karya sastra yang menjadi pokok, alat tentang apa yang tersirat dalam karya sastra tersebut dan apa tujuan serta amanat yang hendak disampaikan. Dapat disimpulkan bahwa sosiologis merupakan menelaah sastra dengan memperhatikan segi-segi sosial kemasyarakatan.

\section{METODE PENELITIAN}

Penelitian pada novel Sebelas Patriot karya Andrea Hirata menggunakan metode kualitatif. Menurut Semi (1993:9) metode 
kualitatif yaitu sebuah metode yang digunakan untuk mengolah data dengan tidak mengutamakan angka-angka, tetapi menggunakan kedalaman penghayatan terhadap interaksi yang sedang dikaji secara empiris. Metode kualitatif berusaha mengungkap berbagai keunikan yang terdapat dalam individu, kelompok, masyarakat, dan/atau organisasi dalam kehidupan sehari-hari secara menyeluruh, rinci, dalam, dan dapat dipertanggungjawabkan secara ilmiah.

Tahap analisis data, penulis akan mendeskripsikan analisis struktural dan aspek sosial. Langkah pertama yang dilakukan penulis untuk menganalisis data, yaitu menganalisis novel Sebelas Patriot dengan menggunakan analisis struktural, kemudian langkah kedua yaitu menganalisis novel Sebelas Patriot dengan tinjauan aspek sosial.

\section{HASIL DAN PEMBAHASAN}

Hasil dan pembahasan pada novel Sebelas Patriot karya Andrea Hirata dianalisis oleh dua aspek, yaitu:

\section{Analisis Struktural}

Analisis struktural meliputi:

a. Judul

Judul dalam novel Sebelas Patriot karya Andrea Hirata menunjukkan objek yang dikemukakan dalam suatu cerita.

\section{b. Tema}

Tema merupakan gagasan pokok yang terkandung dalam cerita. Tema yang terdapat dalam Sebelas Patriot karya Andrea Hirata adalah membela negara dapat dilakukan melalui olah raga.

Biarlah, biarlah sebab selebihnya, aku dan ayahku semakin setia pada PSSI. Silahkan kau, atau siapa saja, berkata apa. Silahkan orang ngomelngomel melihat PSSI kalah, cinta kami tetap pada PSSI (Sebelas Patriot:64).

Ikal bercita-cita menjadi pemain PSSI, akan tetapi ia gagal, kegagalannya tidak membuatnya membenci PSSI. Ia tidak pernah ikut-ikutan orang yang mengejek PSSI jika PSSI kalah. Ia tidak pernah menghiraukan perkataan orang-orang yang mengejek PSSI bahkan ia semakin cinta terhadap sepak bola tanah air. Cintanya terhadap PSSI semakin kuat.

\section{c. Penokohan dan Perwatakan}

Tokoh utama novel Sebelas Patriot adalah Ikal. Ikal tidak mudah putus asa, meskipun telah gagal mencapai citacitanya ia tetap berusaha dalam kesempatan lainnya. Ikal juga memiliki sifat cinta terhadap tanah air, ia ingin menggapai cita-citanya, dan juga memiliki sikap giat bekerja. Hal itu terlihat pada kutipan berikut: 
Pada kesempatan-kesempatan

berikutnya aku kembali mengikuti seleksi dengan tujuan utama yaitu menjadi pemain PSSI. Karena aku bersi kukuh ingin mengambil posisi sayap kiri di PSSI yang menurutku telah dirampas Belanda secara tak tahu adat dari tangan Ayah (Sebelas Patriot:60).

Waktu itu Ikal telah gagal menjadi pemain junior PSSI. Ia ingin mencoba kembali ikut seleksi untuk menjadi pemain junior PSSI, ia tidak menyerah begitu saja. Tujuan Ikal adalah hanya menjadi pemain junior PSSI karena ingin menggantikan posisi ayahnya. Pada jaman penjajahan Belanda, ayahnya menjadi pemain sayap kiri membela tim kuli parit tambang. Tempurung kaki kiri ayah Ikal hancur karena ulah Belanda, karena pada waktu itu tim kuli parit tambang bertanding mengalahkan tim Belanda gol satu-satunya yang disumbangkan oleh ayah Ikal.

Tokoh bawahan atau tokoh tambahan adalah tokoh yang kehadirannya berhubungan dengan tokoh utama baik secara langsung ataupun secara tidak langsung. Tokoh-tokoh dalam novel Sebelas Patriot karya Andrea Hirata adalah:

1) Ayah

Ayah bekerja menjadi kuli di PN timah, bergegas naik sepeda dan bergegas pula pulangnya. Menerima gaji kecil dan beras 60 kilogram setiap tanggal 1. Selalu, begitu, tetap, bertahun-tahun (Sebelas Patriot:2-3).

Ayah Ikal bekerja menjadi kuli di PN timah yang hanya bisa dijangkau dengan sepeda, karena pada waktu jaman penjajahan Belanda belum ada motor yang masuk ke Indonesia. Dengan sepeda sederhananya itulah ia tekun bekerja demi mencari rejeki untuk keluarganya meskipun gaji yang diterimanya hanya beras seberat 60 kilogramnya. Ia melakukan semua itu karena tidak ada pilihan lain untuk menghidupi keluarganya. Ayah merupakan tokoh berwatak datar dan memiliki watak penyayang, pendiam, dan tekun. Ia juga sangat bertanggung jawab terhadap keluarga.

2) Pelatih Toharun

Pelatih Toharun datang ke lapangan memakai pakaian training yang lengkap. Ia tampak sangat sporty. Asistennya tergopoh- gopoh, berlarilari ke sana kemari, juga tak tahu maksudnya apa. Mungkin mereka tak berani kelihatan bersantai-santai saja di depan pelatih toharun, kalau tidak mau kena semprot habishabisan. Setahuku, salah seorang asisten pelatih toharun itu pernah dirawat di rumah sakit jiwa. (Sebelas 
Patriot:38-39).

Pelatih Toharun adalah pelatih sepak bola Ikal di kampung. Ia datang dengan memakai training. Ia tampak sporty dengan membawa peluit yang digantung di lehernya. Asisten pelatih Toharun jika mendengar suara peluit, tidak berani bersantai-santai seperti ketika pelatih Toharun belum masuk lapangan sepak bola. Ikal takut kepada pelatih Toharun, karena ia mudah marah dan sering memarahi asistennya jika ia kelihatan bersantai-santai. Pelatih Toharun memiliki watak pemarah dan pintar.

\section{3) Adriana}

Adriana adalah seorang perempuan cantik yang bekerja sebagai penjaga sekaligus memiliki toko yang terletak di markas besar Real Madrid yaitu tepatnya di stadion Santiago Bernabeu. Ia memiliki sifat ingin tahu, dan suka memberi. Hal tersebut terdapat dalam kutipan berikut.

Adriana seperti berusaha keras mengingat sesuatu, namun gagal.

“Ada sebutankah bagi penggilanya?" "Setahuku belum ada, kuharap para penggemar PSSI akan menyebut diri mereka Patriot PSS." (Sebelas Patriot:87).

Adriana dan Ikal sedang mengobrol tentang tim favorit. Ikal mengatakan kalau Madrid tim sepak bola favorit keduanya, ia pernah bercita-cita dan sangat cinta terhadap sepak bola tanah air. Tim sepak bola favorit pertamanya adalah PSSI. Adriana memiliki watak selalu ingin tahu dan pintar.

\section{d. Konflik}

Konflik antara manusia dan masyarakat terjadi antara Ikal dan tim penjajah. Kejahatan yang dilakukan penjajah juga diakui oleh sang Pemburu. Kisah kekejaman Van Holden terhadap ayah dan saudara-saudaranya diuraikan secara langsung oleh sang Pemburu kepada Ikal. Hal itu terlihat pada kutipan berikut.

Dari pemburu kemudian aku tahu soal Van Holden dan piala Distric beheerder. Aku tahu soal perlakuan diskriminatif dan kekejaman penjajah pada olahragawan lokal. Dadaku mau meledak mendengar kisah Ayah dan kedua abangnya di lapangan hijau dan betapa mereka dulu pernah menjadi inspirasi bagi banyak orang (Sebelas Patriot:27).

Ikal mengetahui kisah tentang kekejaman penjajah dan perjuangan tiga saudara dalam memenangkan piala Distric beheerder dari sang Pemburu. Ia merasa kecewa terhadap sikap yang ditunjukkan pimpinan penjaja yaitu Van Holden ketika memimpin bidang perekonomian di pulau Bangka dan Belitung. Van Holden memerintah kepada bawahannya dengan 
perlakuan yang kejam dan diskriminatif terhadap penduduk pribumi dan keturunan Tionghoa. Van Holden tidak segan-segan melakukan apapun untuk mendapatkan keuntungan yang sebesar-besarnya bagi pemerintahan Belanda.

\section{e. Latar}

Latar atau setting merupakan elemen fiksi yang menunjukkan di mana dan kapan kejaian dalam cerita berlangsung. Latar yang terdapat dalam novel Sebelas Patriot karya Andrea Hirata adalah sebagai berikut.

\section{1) Latar Tempat}

Latar tempat dalam novel Sebelas Patriot karya Andrea Hirata terjadi di Indonesia dan di negara Spanyol karena tokoh dalam novel ini harus ke berbagai tempat untuk memenuhi keinginannya, yaitu:

\section{a) Pulau Belitung}

Pulau Belitung adalah tempat tinggal keluarga Ikal dan ayahnya. Pulau Belitung adalah pulau penghasil timah, hal ini yang mengakibatkan Belanda ingin mengambil timah di pulau Belitung. Hal tersebut terdapat dalam kutipan berikut.

Telah kutemukan dalam buku sejarah, bahwa timah berlimpah di pulau kami Belitung, membuat Belanda bernafsu mengeruk sebanyak-banyaknya. Berebut kuasa sesama kolonial menambah ambisi sebanyak-banyaknya itu dengan secepat- cepatnya. Dalam putaran kerakusan nan dahsyat itu anak-anak lelaki Melayu di bawah umur diseret ke parit-parit tambang untuk kerja rodi (Sebelas Patriot:5).

Ikal menemukan sebuah buku yang di dalamnya menjelaskan tentang kekayaan alam di pulau Belitung yang berupa timah. Belanda berambisi ingin mengambil timah yang terdapat di pulau tersebut. Belanda mempekerjakan anak-anak kecil Melayu di bawah umur untuk bekerja rodi.

\section{b) Kota Madrid}

Selama hampir satu bulan Ikal dan Arai merantau, mereka sampai di Spanyol. Mereka harus berpisah karena Arai ingin pergi ke Alhambra sedangkan Ikal pergi ke Madrid. Hal tersebut terdapat dalam kutipan berikut.

Setelah hampir sebulan berkelana, kami sampai di Spanyol dan harus berpisah arah untuk sementara. Arai meminati Alhambra dan aku harus ke Madrid. Keadaan keuangan kami sangat kritis waktu itu, namun aku telah berhemat-hemat untuk mengamankan sejumlah uang demi membelikan ayah kaus bertuliskan Luis Figo di punggungnya, di toko resmi Real Madrid, di markas besar klub itu di Stadion Santiago Bernabeu (Sebelas Patriot:70). 
Waktu itu keuangan Ikal sangat sedikit, akan tetapi Ikal masih harus menghemat uangnya untuk membelikan ayahnya kaus yang ada nama Luis Figo di punggungnya. Ikal ingin membelikan kaus ayahnya tersebut di toko resmi Real Madrid yang letaknya di markas besar klub Real Madrid yaitu di stadion Santiago Bernabeu.

\section{c) Barcelona}

Ikal ingin mencari pekerjaan di Barcelona, karena di tempat itu terdapat semacam kiblat bagi para pengelana. Ia bertanyatanya tentang pekerjaan kepada sesama pengelana yang datang ke kota itu. Hal tersebut ada dalam kalimat berikut.

Dari Santiago Bernabeu aku bergegas menuju stasiun kereta terdekat dan meluncur ke Barcelona. Di Barcelona aku segera ke Placa de Catalunya. Tempat itu sudah menjadi semacam kiblat bagi para backpacker. Kepada sesama backpacker, aku bertanya tentang pekerjaan-pekerjaan cepat dengan bayaran per jam. Di beberapa kota menggunakan tenaga backpacker telah menjadi kebiasaan setelah musim panas (Sebelas Patriot:77-78). Ikal yang semula berada di kota Real Madrid langsung menuju Barcelona untuk mencari pekerjaan, karena di kota itu terdapat sebuah tempat berkumpulnya para pengelana lainnya. Ia bertanya kepada sesama pengelana tentang pekerjaan cepat dengan bayaran per jam, dan kebetulan di beberapa kota sedang membutuhkan tenaga pengelana untuk menjadi buruhnya.

\section{d) Toko resmi Real Madrid}

Ikal kembali ke kota Madrid setelah berhasil mengumpulkan uang untuk membelikan kaus pemain favorit ayahnya. Setelah tiba di toko resmi Real Madrid, ia langsung menuju ke lemari tempat kaus itu disimpan. Hal tersebut ada dalam kutipan sebagai berikut.

Dengan napas tersenggal-senggal, aku sampai di toko resmi Real Madrid dan langsung menghambur ke lemari di mana kaus itu di-display. Namun, betapa kecewanya karena yang tampak hanya tinggal bingkainya, kausnya tak ada. Sesorang telah membelinya. Aku melihat sekeliling berharap kaus itu masih ada, hanya letaknya yang dipindahkan. Namun kaus itu tidak tampak (Sebelas Patriot:83-84).

Ikal sampai di toko resmi Real Madrid dengan napas yang tidak teratur. Ia langsung menuju ke lemari tempat kaus pemain favorit ayahnya tersebut disimpan. Akan tetapi ia sangat kecewa karena yang tampak di lemari itu hanyalah bingkainya saja, sedangkan kausnya tidak ada. Ia telah mengira bahwa kaus itu telah dibeli 
oleh sesorang. Ikal mencoba melihat sekelilingnya dan berharap kaus itu masih ada, hanya letaknya saja yang dipindahkan. Akan tetapi teryata kaus itu tidak ada.

\section{e) Nou Camp}

Ikal juga sempat mengunjungi Nou Camp, yaitu markas besar klub sepak bola Barcelona. Klub sepak bola Barcelona adalah klub favorit Ikal yang lainnya. Hal tersebut ada dalam kutipan berikut. Setiap ada kesempatan, aku mengunjungi Nou Camp, markas besar klub kegemaranku lainnya, yaitu Barcelona FC. Di toko resmi Barca aku membeli kaus yang akan kukirimkan untuk pelatih Toharun dan dipekarangan Nou Camp kutemukan bus museum Barcelona FC yang terkenal itu (Sebelas Patriot:78).

Ikal mengunjungi Nou Camp setiap ada kesempatan, Nou Camp terletak di markas besar Barcelona yaitu klub favoritnya yang lainnya. Ikal membeli kaus di toko resmi Barcelona, kaus itu akan dikirimkan kepada pelatih sepak bolanya yaitu pelatih Toharun. Bus yang dipakai pemain barcelona dulu ada di halamn Nou Camp dan sekarang bus itu telah dimuseumkan.

\section{2) Latar Waktu}

Latar waktu merupakan latar yang berkenaan dengan situasi waktu pada saat peristiwa terjadi. Dalam novel Sebelas Patriot disebutkan beberapa latar waktu yang meliputi hari lahir Ratu Belanda, sore hari, dan malam hari.

a) Hari lahir Ratu Belanda

Hari lahir Ratu Belanda diperingati di seluruh tanah jajahan Belanda, termasuk di Belitung. Peringatan kelahiran Ratu Belanda disemarakkan dengan perayaan pertandingan kompetisi piala Distric beheerder. Berikut data yang mendukung. Ironi yang sesungguhnya terjadi. Van Holden memerintahkan agar hari lahir Ratu Belanda diperingati di tanah jajahan. Orang-orang Melayu dipaksa memeriahkan hari kelahiran ratu dari bangsa yang terangterangan di siang bolong menindas mereka. Perayaan itu ditandai dengan pertandingan olahraga dalam kompetisi piala Distric beheerder (Sebelas Patriot:12).

Van Holden telah memerintahkan segenap penduduk pribumi untuk berpartisipasi memperingati perayaan kelahiran Ratu Belanda. Ia memerintahkan penduduk Belitung untuk mengikuti pertandingan olahraga kompetisi piala Distric beheerder. Van Holden mewajibkan segenap penduduk Belitung mengikuti kompetisi itu, apabila ada yang melanggar ketentuannya, akan dijatuhi hukuman. 
b) Sore hari

Sore hari merupakan latar waktu saat Ikal bertemu dengan Nyonya Vargas. Hal tersebut dapat dilihat melalui kutipan data berikut.

Sore itu aku berjumpa dengan Nyonya Vargas. Ia memberiku sejumlah uang. Uang yang kugenggam kuat-kuat, terselip di celah-celah jemariku. 250 euro terkumpul sudah (Sebelas Patriot:83).

Ikal berjumpa dengan Nyonya Vargas saat sore hari. Pertemuan keduanya memang disengaja. Ikal sengaja menemui Nyonya Vargas untuk mengambil gaji yang telah dijanjikan Nyonya Vargas sebagai imbalan atas pekerjaan yang telah dilakukannya. Ikal bekerja keras siang dan malam mengumpulkan uang untuk membeli kaos yang bertandatangankan Luis Figo.

c) Malam hari

Latar malam hari merupakan waktu yang digunakan Ikal untuk bekerja sebagai pembantu umum pada klub sepak bola Barca. Ambisinya untuk membeli kaos Luis Figo untuk ayahnya tidak membuatnya berputus asa meski pekerjaannya berat.

Malam itu aku langsung bekerja dan merasa senang berada di dekat bakatbakat muda Spanyol. Sungguh mengagumkan. Bola begitu lengket di kaki mereka. Kubayangkan mereka nanti berlaga di liga premier. Pekerjaan ini tak masalah bagiku karena ku tak asing dengan klub dan lapangan bola (Sebelas Patriot:81).

Berdasarkan data tersebut dapat diketahui bahwa Ikal menghabiskan waktu malam hari untuk bekerja di stadion tempat latihan tim Barcelona FC. Ia bekerja sebagai pembantu umum klub junior Barca. Pekerjaan yang dilakukannya setiap malam tidak membuatnya merasa terbebani, justru ia sangat mencintai pekerjaannya.

\section{3) Latar Sosial}

Novel Sebelas Patriot berlatar tempat di Belitung yang berlatar sosial penduduk Melayu. Belitung merupakan bekas jajahan pemerintah kolonial Belanda di bawah pimpinan Van Holden. Kehidupan masyarakat Belitung berada dalam kemiskinan.

$\mathrm{Aku}$ telah melihat orang-orang seperti Ayah ketika mereka baru bekerja, dan ketika mereka pensiun. Maka aku dapat membayangkan seperti apa ayah waktu masih muda dulu, begitu pula Ayah tahun depan, dan setelah tahun depan itu. Pun jika Ayah meninggal, serta berapa lama orang- orang akan mengenangnya (Sebelas Patriot:3).

Semua penduduk Belitung yang bekerja sebagai kuli buruh di PN Timah 
memiliki nasib yang sama dengan Ayah Ikal. Mereka hidup dalam kemiskinan meskipun kekayaan bumi di tempat tinggal mereka sangat melimpah. Masyarakat pribumi dipaksa bekerja keras dan digaji dengan upah yang sangat sedikit, tidak cukup untuk memenuhi kebutuhan seharihari. Keadaan itu akan berlanjut sampai para kuli buruh berhenti. Pendapatan mereka tidak mengalami peningkatan sehingga mereka tidak dapat meningkatkan kemampuan ekonomi keluarga.

\section{Aspek Sosiologis}

Novel ini kondisi sosial budaya terbagi menjadi tiga, yakni

a. Kondisi sosial budaya zaman pemerintahan belanda di Belitung

Pada zaman pemerintahan belanda di belitung diceritakan bahwa para penduduk belitong dipaksa untuk kerja rodi. Hal itu terlihat pada kutipan berikut.

Seluruh kekeyaan alam terutama timah yang ada di belitong dikeruk habis. "telah kutemukan dalam buku sejarah, bahwa timah berlimpah di pulau kami belitong membuat belanda bernafsu mengeruk sebanyak-banyaknya. Dalam putaran kerakusan nan dahsyat itu anak-anak lelaki melayu dibawah umur diseret ke parit-parit tambang untuk kerja rodi (Sebelas Patriot:6).
Para penduduk diperas tenaganya hanya untuk memberi keuntungan kepada belanda. Harga diri rakyat belitong diinjakinjak oleh belanda. Masalah sepele yang dibuat oleh orang Indonesia selalu dibesarbesarkan. Keadaan sosial pada saat itu sangat memprihatinkan. Anak-anak kecil dipaksa meninggalkan rumah untuk dijadikan pekerja bagi belanda. Bahkan ayah ikal dan kedua saudaranya mengalami nasib pahit tersebut di era pemerintahan belanda. Pada zaman pemerintahan belanda, ayah ikal dan kedua saudara kandungnya menjadi bintang sepak bola saat kelihainnya dalam bermain bola disanjung oleh masyarakat. Sampai-sampai Van Holden ingin menyaksikannya sendiri. Van Holden terpana melihat kepiawaian tiga bersaudara itu menggiring bola, sayap kiri ayah ikal, gelandang dan sayap kanan. Pada suatu ketika ketiga saudara tersebut dilarang bermain bola saat pertandingan melawan pemuda belanda. Tapi ketiga saudara itu tetap bersikeras dalam mengikuti pertandingan dengan modal nekat. ketiga saudara itu bermain dengan pemuda belanda dan memalukannya di mata orang banyak. Saat seperti itulah sebuah kemerdekaan muncul walaupun hanya di lapangan. Akibar dari kenekatan ketiga pemuda itu, sebagai gantinya tentara belanda membuat ketiga pemain tersebut babak belur dan juga pelatihnya. 
b. Kondisi sosial budaya ketika di benua eropa

Kondisi sosial di benua eropa sangat berbeda dengan kondisi budaya di Belitong. Ikal melakukan sebuah perjalanan jauh dari perancis menjelajahi eropa, menjadi seorang pengelana. Hal itu terlihat pada kutipan berikut.

Ikal ingin menuju ke Madrid. Dimana kota yang menghasilkan pemain sepak bola yang digandrungi oleh ayahnya. Ikal dengan arai menuju ke Spanyol tapi mereka berdua berbeda tujuan. Setelah hampir sebulan berkelana, kami sampai di spanyol dan harus berpisah arah untuk sementara. Arai meminati Alhambra dan aku harus kemadrid (Sebelas Patriot:70)

Tujuan ikal kemadrid yaitu untuk membelikan kaos bertanda tangan luis figo yang akan dihadiahkan untuk ayahnya. Ikal mendapat kaos bertanda tangan itu dengan susah payah, dia harus bekerja seperti kacung menjadi pembantu untuk mencari uang 250 euro. Akhirnya ikal bisa membeli kaos bertanda Tangan Lusi Figo, berkat bantuan Andriana. Sosial budaya di daerah eropa sangat memengaruhi pola kehidupan ikal. Kehidupan ikal begitu keras menjadi backpacker, yang lebih memengaruhi lagi dalam hubungan sosial budaya dalam pada tokoh yang bernama ikal yakni, sejarah ayahnya di masa pemerintahan belanda dan kehidupannya saat dikampung belitong dididik oleh pelatih tohari yang keras dan displin, membuatnya menjadi seorang pekerja keras.

\section{c. Proses Sosial}

Proses sosial yang terjadi dalam masyarakat berkaitan erat dengan interaksi sosial. Menurut Soekanto, (2003:66) proses sosial terjadi karena adanya pengaruh timbal-balik antara berbagai segi kehidupan bersama. Interaksi sosial terbagi atas empat hal yaitu kerjasama, pertentangan, persaingan, dan kemiskinan. Hal tersebut dijelaskan sebagai berikut.

1) Kerjasama

Waktu demi waktu berlalu. Tertindas di bawah penjajahan, rakyat menemukan caranya sendiri untuk melawan. Para penyelam tradisional melawan dengan membocorkan kapal-kapal dagang Belanda yang mendekati perairan Belitung. Para pemburu melawan dengan meracuni sumur-sumur yang akan dilalui tentara Belanda. Para imam membangun pasukan rahasia di langgar-langgar. Para kulit parit tambang melawan dengan sepak bola (Sebelas Patriot:6)

Masyarakat di Belitung bekerja sama berjuang mengusir penjajah dari Belitung. Mereka bekerja sama mengisi kekuatan 
yang ada dari berbagi bidang. Seperti yang dilakukan para penyelam, dengan cara membocorkan kapal-kapal dagang Belanda, meracuni sumur yang akan dilewati tentara Belanda, membangun langgar, dan melawan melalui bidang olahraga seperti sepak bola. Sepak bola merupakan olah raga bergengsi yang dapat mengangkat harkat dan martabat penduduk Belitung. Saat kekuasaan tidak lagi menghasilkan kemerdekaan dalam diri seseorang, melalui sepak bola masyarakat Belitung dapat merasakan kebebasan dan dapat merasakan perjuangan yang nyata.

\section{2) Pertentantangan}

Soekanto (2003:102) mengungkapkan bahwa pertentangan terdapat dua macam, yaitu pertentangan pribadi dan pertentangan antarkelompok. Pertentangan pribadi adalah pertentangan yang dilakukan oleh dua individu yang masingmasing mempunyai rasa benci dan bisa juga mengakibatkan perkelahian fisik. Pertentangan antar kelompok, adalah pertentangan yang disebabkan oleh perbedaan kepentingan atau kelas sosialnya dalam suatu kelompok atau masyarakat.

Pertentangan Pribadi

Pada kesempatan-kesempatan berikutnya aku kembali mengikuti seleksi dengan tujuan utama yaitu menjadi pemain PSSI. Karena aku bersikukuh ingin mengambil posisi sayap kiri di PSSI yang menurutku telah dirampas Belanda secara tak tahu adat dari tangan Ayah (Sebelas Patriot:60).

Berdasarkan data tersebut dapat diketahui bahwa kekecewaan Ikal terhadap pemerintah kolonial Belanda yang telah menghapus keinginan ayahnya untuk menjadi pemain profesional. Ayah Ikal adalah pemain bola yang hebat, namun karena kejahatan pihak pemerintah Belanda yang dipimpin oleh Van Holden, membuatnya terpaksa menghapus keinginannya untuk menjadi pemain bola, ketika tempurung kakinya dipecahkan oleh Belanda. Tekatnya sudah bulat untuk menjadi pemain sepak bola dan berjuang untuk bergabung dalam PSSI. Keinginannya itu didasari karena ia ingin membahagiakan ayahnya, ia ingin dapat melanjutkan perjuangan ayahnya sebagai pemain sayap kiri yang hebat seperti ayahnya.

\section{Pertentangan antarkelompok}

Pernah tercatat beberapa perlawanan yang pernah diletuskan rakyat. Namun, kaum yang rendah hati dan turun-temurun tak mengenal kekerasan itu selalu diberi contoh mengerikan atas niat pemberontakan. Belanda tang sungkan membakar kampung dan 
membunuh setiap orang tak peduli wanita, anak-anak, dan orang tua. Dengan cara keji ini kolonial melanggengkan kerja paksa bagi pribumi (Sebelas Patriot:6).

Pertentangan masyarakat Belitung terhadap kekuasaan anarkis yang dilakukan pemerintah kolonial Belanda pernah dilakukan dengan berbagai cara, namun belum membuahkan hasil. Pemerintah Belanda masih saja berkuasa di tanah Belitung dan mengeruk sebanyakbanyaknya harta kekayaan alam yang berupa timah yang berlimpah. Selain itu, pemerintah Belanda juga mempraktikkan sistem kerja paksa kepada penduduk Belitung. Setiap yang menolak pada ketentuan yang berlaku akan mendapatkan sangsi yang sangat kejam dan menyakitkan. Mereka tidak segan-segan membunuh atau membuang ke pulau pengasingan sehingga tidak dapat berkumpul kembali dengan keluarganya. Sikap keji yang ditunjukkan Belanda itu pulalah yang pada akhirnya menimbulkan semangat pemberontakan melawan kekuasaan penjajah di Belitung.

\section{3) Persaingan}

Soekanto (2003:99) berpendapat bahwa persaingan mempunyai dua tipe umum yakni yang bersifat pribadi dan tidak pribadi. Persaingan yang bersifat tidak pribadi biasanya dilakukan antara kelompok satu dengan kelompok lain, misalnya persaingan dua perusahaan besar dalam mendapatkan monopoli di dalam suatu wilayah tertentu. Dalam kenyataannya persaingan sering berdampak negatif bagi individu maupun kelompok, karena persaingan dapat menimbulkan pertentangan atau pertikaian. Perayaan itu ditandai dengan pertandingan olahraga dalam kompetisi piala Distric beheerder. Orang jajahan bertanding sesama orang jajahan, atau Belanda melawan orang jajahan. Tapi tentu saja, sehebat bagaimanapun, orang jajahan tidak boleh menang melawan penjajah (Sebelas Patriot:12).

Persaingan yang tidak sportif terjadi antara tim Belanda melawan tim jajahan (pribumi). Semua tim yang tergabung dalam PN Timah Belitung harus mengikuti pertandingan Distric beheerder. Setiap tahun pertandingan itu diselengggarakan oleh pihak pemerintah Belanda yang berada di Belitung yang dipimpin oleh Van Holden. Pertandingan tersebut tidak berjalan seperti biasanya, banyak terdapat intrik dan kecaman saat pertandingan. Tim Belanda selalu berusaha agar tim mereka dapat menjadi juara pada pertandingan yang dilaksanakan setiap setahun sekali. Oleh sebab itu, setiap ada pertandingan, mereka mewajibkan kepada tim mana pun untuk mengalah demi nama baik tim 
Belanda. Mereka tidak segan-segan mengancam, bahkan melakukan tindakan kekerasan fisik apabila ada yang berani melawan kekuasaan penjajah.

\section{4) Kemiskinan}

Ayah bekerja menjadi kuli di PN timah, bergegas naik sepeda dan bergegas pula pulangnya. Menerima gaji kecil dan beras 60 kilogram setiap tanggal 1. Selalu, begitu, tetap, bertahun-tahun (Sebelas Patriot:2).

Berdasarkan data tersebut dapat diketahui bahwa Ayah Ikal telah banyak menghabiskan waktunya sebagai pekerja kasar di PN Timah Belitung. Ayah Ikal telah bekerja selama bertahun-tahun, namun tetap saja tidak mendapatkan materi yang cukup dari hasilnya bekerja. Ia hanya mendapat gaji kecil dan beras seberat 60 kilogram. Upah itu tentu saja tidak sesuai dengan kebutuhan hidup yang semakin hari semakin meningkat.

\section{SIMPULAN}

Analisis terhadap novel Sebelas Patriot karya Andrea Hirata menggunakan analisis struktural dan aspek sosial. Setelah dilakukan analisis diperoleh kesimpulan sebagai berikut. Judul dalam novel Sebelas Patriot karya Andrea Hirata menunjukan objek. Sebelas Patriot diambil dari keinginan Ikal untuk membahagiakan orang tuanya yang dulu pernah gagal menjadi pemain sepak bola.

Tema novel Sebelas Patriot adalah membela negara dapat dilakukan melalui olahraga. Tokoh utamanya adalah Ikal karena merupakan tokoh yang paling banyak diceritakan, paling banyak berhubungan dengan tokoh-tokoh lain dan paling banyak membutuhkan waktu penceritaan. Tokoh Ikal berwatak datar karena hanya memiliki satu kualitas pribadi tertentu, satu sifat-watak yang tertentu saja. Ikal pekerja keras, pintar dan tidak mudah putus asa. Tokoh bawahannya adalah Ayah, pelatih Toharun, dan Adriana yang keseluruhannya mempunyai watak datar. Konflik dalam novel ini yaitu konflik eksternal dan konflik internal. Latar dalamnya meliputi latar tempat, latar waktu dan latar sosial. Latar tempatnya yaitu pulau Belitung, kota Madrid, Barcelona, toko resmi Relam Madrid, dan Nou Camp. Latar waktu meliputi Hari lahir Ratu Belanda, sore hari dan malam hari. Latar sosial masyarakat belitung adalah penduduk Melayu. Belitong merupakan bekas jajahan pemerintah kolonial Belanda di bawah pimpinan Van Holden. Kehidupan masyarakat Belitong berada dalam kemiskinan. Analisis aspek sosial dalam novel Sebelas Patriot karya Andrea Hirata meliputi proses sosial dan masalah sosial. Proses sosial meliputi kerjasama, pertentangan, dan persaingan. Kerjasama 
dilakukan antarkelompok masyarakat Belitong dalam mengusir kekuasaan pemerintah kolonial Belanda. Bentuk kerjasama juga dilakukan oleh tiga saudara yang membuat Van Holden kagum pada kekompakan tiga saudara. Pertentangan dalam novel ini ada dua yaitu pertentangan pribadi dan pertentangan antar kelompok. Pertentangan pribadi dilakukan ayah Ikal dengan Van Holeden karena sikapnya yang kejam kepada masyarakat Belitong. Masalah sosial dalam novel Sebelas Patriot karya Andrea Hirata meliputi kemiskinan yang dialami Ayah Ikal yang termasuk masyarakat Belitung yang disebabkan oleh penjajahan Belanda. Kemiskinan lainnya juga dialami oleh Ikal saat berada di Spanyol.

\section{SARAN}

Sehubungan dengan simpulan dalam laporan hasil analisia maka dapat diperoleh aspek sosial novel Sebelas Patriot karya Andrea Hirata yaitu dalam mewujudkan cita-cita atau keinginan, membutuhkan usaha, doa, dan kerja keras, dalam menjalani kehidupan seseorang akan merasakan suatu kegagalan. Kegagalan hendaklah tidak membuat kita putus asa dan setiap manusia membutuhkan orang lain sebagai penyemangat atau motivasi dalam hidup.

\section{DAFTAR PUSTAKA}

Endraswara, Suwardi. 2013. Teori Kritik Sastra. Yogyakarta: CAPS

Hirata, Andrea. 2011. Sebelas Patriot. Yogyakarta: Bentang.

Nurgiyantoro, B. 2000. Teori Pengkajian Fiksi. Yogyakarta: Gadjah Mada University Press.

Semi, M. A. 1993. Metode Penelitian Sastra. Bandung: Angkasa.

Siswanto. 2005. Sastra Indonesia dan Tradisi Sosial. Jakarta: Gramedia.

Soekanto, S. 2003. Sosiologi Suatu Pengantar. Jakarta: PT Raja Grafindo Persada.

Teeuw, A. 1983. Membaca dan Menilai Sastra. Jakarta: Gramedia.

Wellek, Rene dan Austin Warren. 1977. Teori Kesusastraan. Jakarta: Gramedia 